\title{
ON NEW PATHS IN VEGETATION SCIENCE AND LANDSCAPE ECOLOGY: IN MEMORIAM PROF. GÁBOR FEKETE
}

\author{
Zs. MolnáR ${ }^{1 *}$, S. Bartha ${ }^{1}$ and A. Kun ${ }^{2}$ \\ ${ }^{1}$ Institute of Ecology and Botany, MTA Centre for Ecological Research \\ H-2163 Vácrátót, Alkotmány u. 2-4, Hungary; ${ }^{*}$ E-mail: molnar.zsolt@okologia.mta.hu \\ ${ }^{2} \mathrm{H}-8699$ Somogyvámos, Fö u. 62, Hungary
}

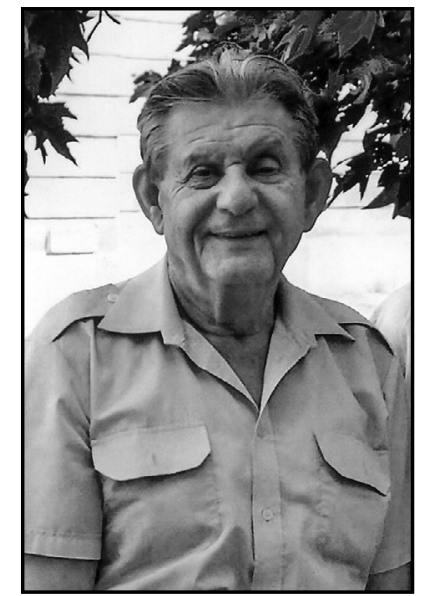

Gábor Fekete academician respectfully but affectionately called 'Master' ("Tanár Úr" in Hungarian, a version of 'Professor' that we used with a specific meaning of being not only a Tutor but Father and Master as well) by generations of vegetation scientists passed away on the 29th November 2016. His death deprived us of an experienced and didactic teacher who was loved by all. This warm regard was expressed in many commemorating writings published since his death. The present paper mainly concentrates on his scholarly work and the importance of his scientific findings also showing how particular publications signify stages in his scientific career.

\section{EDUCATION AND EARLY CAREER}

Gábor Fekete was born in Budapest, on the 20th April 1930. His family moved to Székesfehérvár in 1936, and he graduated from the Szent István Gimnázium, a high school run by the Cistercians. He played water polo, played the piano, and his favourite subject was chemistry. In 1948 he applied 
to the Technical University but was denied because of his middle-class background and ecclesiastic education. Next year, however, he got admission to the biology and chemistry course of Pázmány Péter University (the predecessor of Eötvös Loránd University), where he wanted to become a researcher in chemistry. His contemporaries claim that he was a real benefit to fellow students on account of his knowledge and competence. During his college years his interest gradually turned from chemistry towards botany thanks to Gábor Andreánszky, one of the leading professors of the time. Apart from him, Gábor Fekete was taught by many outstanding Hungarian botanists, such as Rezső Soó, Bálint Zólyomi and Ádám Boros.

\section{BECOMING A STUDENT OF BÁLINT ZÓLYOMI}

He was still a university student at the time of his first remarkable scientific findings. He found a couple of species (Stipa bromoides and Chlorocyperus glaber) new to the Hungarian flora (Fekete 1954, 1959b), and completed the phytosociological monograph of one of the hilly regions in Hungary (called Velencei-hegység) (Fekete 1955). After graduation he was employed by the Botanical Department of the Natural History Museum and was working by the side of Bálint Zólyomi, one of the most outstanding Hungarian vegetation scientists of the 20th century. He took part in vegetation surveys (like the survey of the Bükk Mts) on the frontline of Hungarian phytosociology. He also started to work independently in the Bakony, a mountainous region mostly covered by beech and oak forests and rocky grasslands with Illyrian and subMediterranean elements. The description and analysis of the flora and plant communities revealed that the zonality (climazonal pattern) in this region is different from the one typical in the Pannonian mountains, as the beech forest zone is adjacent to the xerotherm oak forests, while the oak-hornbeam and Turkey oak forest zones are missing (Fekete 1963, 1966, Fekete and Járai-Komlódi 1962, Fekete and Zólyomi 1966). This was the first in a series of important discoveries, which finally led him to write a synthesis of the Pannonian vegetation, and develop a new biogeographical model in 2014 (Fekete et al. 2014, 2016). Meanwhile, he was also studying the Quercus pubescens forests and the distribution of forest-steppe species typical of these forests with Pál Jakucs (Fekete and Jakucs 1957).

\section{PHYTOSOCIOLOGICAL STUDY OF XEROTHERM OAK FORESTS AND FOREST-STEPPE FORESTS IN THE BALKAN}

Based on Zólyomi's methodology he carried out comparative phytosociological studies of the Pannonian xerotherm forests and several regions in the Balkan. In the late 1950s and beginning of 1960s he visited Bulgaria (where 
he made 300 phytosociological relevés in xerotherm oak forests), Romania, the Southern and Eastern Carpathians, Oltenia, Dobruja and Dalmatia (Fekete 1959a, 1967). Afterwards, looking back at this period, he said that "all those travels were rooted in Hungary and motivated by the desire to find analogous plant communities. And we searched for them in Central, Southern and Eastern Europe. We worked intensively and over a large area.".

In the 1950s and 1960s the 'Zólyomi school' was intensely interested in zonality including extra- and intrazonality of plant communities in a given landscape, their spatial relations to each other (neighbourhoods) and their vegetation history during the Holocene. They studied the occurrence of certain rare and characteristic species in relation to different geological, pedological, geomorphological, microclimatic and coenological situations, and species combinations. With the assistance of his students, Zólyomi's dynamic vegetation studies have expanded both in time and space: from small Sphagnum bogs and individual hills to whole mountains and floristical regions and from the Holocene back to the Tertiary. It was an euphoric time for the members of the research team. Wherever they started working within the Pannonian region, the history of surviving vegetation fragments, the geographical origins of various populations, and their relations to neighbouring regions were gradually revealed (see details e.g. in Fekete and Varga 2006, Fekete et al. 2014, Zólyomi and Fekete 1994).

The extensive plant communities with constant dominant and characterspecies combinations were considered 'real communities', thus relevant to Zólyomi and his team, and were therefore the primary objects of study. Both the spatial and temporal scales were large. Their approach to understanding the vegetation in a given area was holistic. The main objective was to explore 'meaning' (e.g. the meaning of indicator characters), 'role' (e.g. as a species refugium) and 'position' (e.g. position in the zonal pattern and also neighbourhood relations) of the different plant communities "in a landscape where human impact was limited. In the early 1960s I thought Bakony was just like that!" - explained Gábor Fekete later.

Life can bring interesting coincidences. On one of his later journeys to the Balkan Gábor Fekete became a lifelong friend of an outstanding Romanian botanist, who recently recalled: "We went to Várna to the 'First Balkan Flora and Vegetation Congress' in 1973. There were six of us, all botanists in the same compartment on the train. The conductor asked what I had there on my seat. That is a plant press - I answered. Someone else on the train has the same device. Where is he from? - I asked. Budapest. I told the colleagues that I spoke Hungarian and would greet him. Good morning! My name is Gavril Negrean. We shook hands, and he said: I am Gábor Fekete. He had the same name (both Negrean and Fekete mean black, while Gavril and Gábor are two versions of the same name). We were friends ever since." 


\section{PHYTOSOCIOLOGICAL AND BIOGEOGRAPHICAL DISCOVERIES IN THE GÖDÖLLŐ HILLS}

The research in Bakony was still going on, when Gábor Fekete started a new project in the Gödöllő Hills. He was intrigued by the vegetation mosaic of forest steppes and their 'immanent dynamism' as he called it. Studying forest steppes was a real challenge, as remnants of this vegetation type in the Carpathian Basin are highly fragmented and considerably transformed and degraded. In the field he soon had to face the fact that these forests do not fit into any of the existing categories of the Hungarian or Central European phytosociological system. The main indicators he used to describe the forest-steppe vegetation in the Gödöllö Hills were the growth forms of trees (and which canopy layer they reached), the vertical structure of the forest, the areal and phytosociological spectrum of the community and the edaphic conditions. He proved by comparative studies that the vegetation of that region is more like the cool continental forest steppes of Southern Russia than the sub-Mediterranean forest steppes of the rest of the Pannonian region. He argued that in case of forest steppe vegetation, it is the mosaic itself that is zonal, rather than the plant communities themselves, and that the macro-area (broad-scale) pattern of species is reflected in their local micro-area (finescale) pattern (Fekete 1965). Although he was the first author to describe a number of plant communities (Ceraso mahaleb-Quercetum pubescentis Jakucs et Fekete 1957, Dictamno-Tilietum cordatae Fekete 1961, Aceri campestri-Quercetum roboris Fekete 1965, Fraxino (excelsiori)-Quercetum petraeae-roboris Fekete 1965, Carpino-Quercetum petraeae-roboris praerossicum Fekete 1965), syntaxonomic categorisation was never a priority of his research (Fekete and Jakucs 1968).

\section{ON NEW PATHS}

At the end of the 1970s the positivist, mainly descriptive phytosociology dominated by data collection and working with a standard methodology got into a crisis. The conditions of field research and the technology of the era were ill-equipped to collect and analyse data extensively at a national scale. As a response to this challenge, several new approaches appeared. Clarifying disputes, the demand for firm scientific foundations and a desire to progress were integral parts of the process. While another outstanding Hungarian ecologist's, Pál Juhász-Nagy's school concentrated on a radical renewal of methodology, Gábor Fekete was searching for new ways and questions with the object of study being in the centre of attention. His intuition, inspiration and questions were often born in the field, and were integrated with the potentials offered by methodological and theoretical innovations. His method was to get to know, to understand and to learn the newest, most advanced theories 
and techniques, and to combine these with his field knowledge on vegetation. This way he could perfectly join the objects (observed vegetation patterns) and the research questions relevant to them. He brilliantly recognised new perspectives, methods and potentials always keeping the prospect of synthesis in mind.

As an integral part of the quest, discussions about the fundamental issues of the discipline were frequent at that time. One of the most important debates was about the individualistic or holistic nature of plant communities. According to the individualistic view, community structure and functioning can completely be derived from the attributes of populations (reductionist approach). According to the opposite theory communities can be considered as emergent phenomena, representing an autonomous level of organisation in their own rights (holistic approach). This issue is widely discussed in the ecological literature. The originality of Gábor Fekete's approach was that from the late 1960s he revealed a series of emergent phenomena by empirical field studies (measurements).

\section{FUNCTIONAL ANALYSIS OF PLANT COMMUNITIES}

In the second half of the 1960s, when Hungary joined the International Biological Programme, attention of researchers shifted from the structural description of communities towards understanding ecological processes and functioning (Fekete 1972, 1995). Gábor Fekete did pioneering works in exploring the causal background of species coexistence in the herb layer of oak forests (Fekete 1972, 1975). His approach was motivated by the methodological foundations in quantitative ecology at that period, and by a general ecological theory of Pál Juhász-Nagy and István Précsényi.

Writing his DSc dissertation in the first half of the 1970s was an exhilarating time in Gábor Fekete's life. His work was complex and extremely versatile: laboratory and field research in quantitative ecology, ecophysiology at individual, population and community levels, microclimatic measurements, growth analysis, production biology, niche studies, germination biology. His first step was to describe the interspecific spatial relationships between plants species (applying spatial series analyses, and describing also higher order multiplets). Then step by step, like a detective, he searched for limiting factors using experiments and brilliant logic. He made one of the first empirical field studies quantifying realised niche relationships of plant species. Furthermore, he was probably the very first to describe multiple niche relationships of 3-species multiplets. He demonstrated that pair-wise niche overlaps are context dependent, i.e. can be conditioned by the presence of other species. It has to be mentioned that present approaches in modern traitbased plant community ecology (50-years-later!) are still based on pair-wise 
niche relationships. His monograph (Doctor of Hungarian Academy Thesis; Fekete 1975) became a standard for subsequent studies.

He also contributed to the Síkfőkút Project, a complex interdisciplinary project describing structure, productivity, nutrient and energy cycles, stability, regulation and conservation of a typical Hungarian oak forest. In a seminal publication with his student Zoltán Tuba he demonstrated (for the first time for terrestrial plant communities) the supraindividual pigment homogeneity (as a specific evidence of stand-scale regulation of photosynthesis) in a multilayered forest community (Fekete and Tuba 1977).

\section{NICHE STUDIES IN SAND GRASSLANDS AND THE EMERGENCE OF SYNPHYSIOLOGY}

From the 1970s he also collaborated with István Précsényi. They studied the niche relationships of 9 selected species in a sandy grassland near the Botanical Institute in Vácrátót (Fekete et al. 1976, 1979, 1980, 1990, 1995). The relatively species-poor open sandy grasslands, limited by a single (predominant) factor (soil moisture), were well-suited to these kinds of studies. The study has shown a correlation between abundance relationships and niche structure (Fekete et al. 1990, 1995). The generalist, dominant species typically had larger niche widths and larger niche overlaps (Précsényi et al. 1977b). In contrast, the niche widths of specialist (and usually rare) species were smaller and were more segregated in niche space (Fekete et al. 1995). These pioneering field studies worked with many species, large sample sizes, and described seasonal dynamics of niche relationships (Précsényi et al. 1977a). In addition to pair-wise relationships, multiplets up to 9-species combinations were also examined (Fekete and Précsényi 1981). Field measurements had been preceded by thorough testing of the sampling methodology (analysing the scale dependence of diversity and productivity) (Fekete et al. 1976).

Later, these studies were extended to non-equilibrium communities using demographic and ecophysiological traits as vital explanatory attributes. Their research on the Great Hungarian Plain has revealed details of plant community organisation along a successional gradient. As early as the 1970s they measured the intraspecific variability of plant traits, and quantified demographic and ecophysiological attributes at the plant, population, and community levels. The results challenged the reductionist approach, as it has been proven that infraindividual and individual level plant characteristics (traits) are not constant, but depend on the context of plant community organisation. These early studies significantly contributed to the development of standscale physiology (cf. Bartha et al. 2010, Fekete 2010; a new discipline also called synphysiology, Tuba and Fekete 1986). After discovering the supraindividual pigment homogeneity in forest, they revealed similar community level regu- 
lation of physiological processes in grasslands. Analyses demonstrated that the variability of stand-scale photosynthetic $\mathrm{CO}_{2}$ assimilation decreases with the progress of succession, in correlation with increasing diversity (Fekete et al. 1988). This result is one of the first evidence proving the diversity-stability relationship under field conditions in natural grassland communities.

\section{STUDIES OF LOESS VEGETATION}

After his moving to the MTA Botanical Institute at Vácrátót in 1978, his interest turned toward the study of species-rich loess grasslands. The main questions of research were: how can the long-term persistence of species-rich and highly organised communities be explained, what characteristics of species determine their inter-specific relationships, and what kinds of mechanisms are responsible for the degradation and regeneration of these grasslands (Fekete and Virágh 1982, Nagy et al. 1994, Szente et al. 1996, Virágh and Fekete 1984). Here Gábor Fekete used complex methods again: approaches of diverse disciplines (demography, ecophysiology, quantitative coenology, vegetation dynamics, and landscape ecology) were applied at various levels of organisation (community complex, community, coalition, population and individual levels). The late 1970s was an era of fine-scale vegetation dynamics studies based on the use of permanent sampling units (marked individuals, permanent plots, or repeated vegetation surveys). These studies, combined with experimental transplanting or species removal, revealed the complexity of micro-successional pathways (Fekete et al. 1998, 2000, Virágh and Fekete 1984). Selective herbicides were used to examine the role of certain species groups in the stability of plant communities (Fekete and Virágh 1982). His paper, written in cooperation with his old master, Bálint Zólyomi, incorporating also the results of the micro-successional studies, is an outstanding synthesis of the loess research of the 1980s (Zólyomi and Fekete 1994).

\section{CONTRIBUTIONS TO THE THEORY OF COMMUNITY ECOLOGY}

From the 1960s onwards new directions of research, concentrating on the functioning, processes and mechanisms, has reformed our understanding of plant communities (Fekete 1985a, 1995, Fekete and Tóthmérész 1993). Contributing to the famous debate about Clementian and Gleasonian plant ecology, one of his most important publications was written in defence of the holistic view of vegetation ("The holistic view of succession reconsidered", Fekete 1992). In this paper he demonstrated that the structure and dynamics of climatically zonal versus edaphic communities are characteristically different. Climatically zonal communities are more deterministic (with more consistent species composition and convergent regeneration processes). He pointed out 
that individualistic and stochastic features of communities can be interpreted within the holistic approach, if the context (i.e. the landscape historical and ecological relations) of vegetation processes are taken into account. Together with pigment homogeneity and reduced variability of $\mathrm{CO}_{2}$ assimilation, the relative stability of community level attributes (i.e. consistent, repetitive species associations and high diversity) is also a (holistic) proof for the existence of supraindividual regulation (Bartha et al. 2010). Gábor Fekete's team proved that both structural and functional coordination increases with succession and decreases with degradation (Bartha et al. 2010, 2011, Fekete et al. 1988).

Motivated by his life-long experience about the degradation of natural vegetation, he was among the first researchers who realised the importance of well-organised comparative field studies with standardised methodology and advanced instrumentation for documenting changes, and for understanding ecological patterns and processes at multiple scales (Bartha et al. 2008, Fekete 1985b, 2004b, Fekete and Molnár 2005, Kovács-Láng et al. 1998). He and Edit Kovács-Láng played significant role in Hungary's joining the International Long-Term Ecological Research network (around 1990, as the second country from Europe). He also helped Edit Kovács-Láng to establish the Kiskun LTER site near Fülöpháza (Kovács-Láng and Fekete 1994, 1995). He led and contributed to several large research projects in the frame of Kiskun LTER, and his enthusiasm in field work inspired many young botanists to join this program. After decades of preparation and organisation, he played a major role in setting up a well-equipped experimental station backed with good information technology, which enabled Kiskun LTER to join the international network of modern, coordinated field experiments.

\section{GÁBOR FEKETE AS A LEADER AND RESEARCH MANAGER}

What was a research team like, and how did it work in the 1980s? By that time, a research team had already been working in Vácrátót at the Botanical Institute, and the official label, 'Fekete team' on their equipment was not just a formality. It was a real team (as we know it today) with various experts from different backgrounds working together on a research program. Based on his wide-ranging knowledge, Gábor Fekete directed his young colleagues towards different disciplines, like population biology, ecophysiology, community ecology and vegetation dynamics (Fekete 1998c). On the other hand the researchers in the team were not employed to work on a restricted task. The projects at the institute formed a thematic framework to assist individual research, and personal academic careers. Each researcher worked on several subtopics within the large program, with relative freedom and a potential to develop. The team functioned like a family, in which Gábor Fekete guided the progress of his colleagues like a father. He encouraged, inspired and, most 
importantly, provided a secure background, an umbrella against the outside world. Research was a gratifying activity with the main objective to study and understand Nature. We talked about 'schools' in those days for a good reason.

Gábor Fekete preferred teaching in the field. The main purpose of his research was to interpret the dynamics of vegetation patterns identified in the field, and to understand the spatial patterns of vegetation and the behaviour of populations at both community and landscape level. The field was an ideal site to discuss these questions and to talk over the day's experiences. Usually a shady area with scattered trees and comfortable undergrowth was chosen for lunch breaks, where a discussion about observations of the day could go on for 1-2 hours.

Around 1980, after a long break, 5-6 young researchers started working at the Research Institute in Vácrátót. In September 1983, Gábor Fekete and Attila Borhidi organised a seminar on vegetation ecology for the new generation, where, beside theoretical questions and sampling methods, various other topics ranging from weed communities to tropical rain forests, were discussed. Not only was it an excellent opportunity for learning for the young members of the team, but also guided them towards further challenging research questions.

On one occasion, Gábor Fekete placed 10-12 successional graphs on the library's big table, all from classic Hungarian vegetation monographs. He went through the topology of these graphs, challenging young scientists by the unknown logic behind these models, and also demonstrating how to develop new research questions, based on the results of the predecessors. Gábor Fekete not only respected his predecessors, but read them as well. His favourite authors were Anton Kerner and Raymund Rapaics, and, of course, Bálint Zólyomi. He was also known to be well-read in the international scientific literature. His daily readings covered every area of supraindividual biology, including works on theoretical ecology, population genetics, ecophysiology, experimental vegetation studies, production biology, landscape ecology, conservation biology and biogeography. His library reflected his diverse interests, ranging from cybernetics to the reclamation of mining areas. Overspecialisation was one of his sore points, especially if it was within a single discipline. He viewed the flora and vegetation as a whole, and encouraged everybody else to do so.

\section{TOWARDS NEW LANDSCAPE-SCALE SYNTHESES}

At the beginning of 1990s Gábor Fekete's attention turned toward landscape-scale studies and the synthesis of vegetation phenomena, primarily the relation of biogeographical and landscape ecological phenomena. As early as in 1965, when he joined Hermann Meusel's international team working on 
the chorological atlas of the European flora, he observed that sometimes even generalist forest and grassland species (like Geranium sanguineum and Convallaria majalis) are missing from the interior regions of the Great Hungarian Plain, the central part of the Pannonian region. He assumed a biogeographical gradient in the background, and his principal interest was the inner inhomogeneity of this gradient. He approached the problem from two different directions: studies were started on landscape ecological patterns as well as on the regional gradients of forest and steppe species. Vegetation maps were never considered a final product by Gábor Fekete, just an intermediate stage in the assessment of an area's vegetation (Fekete 1980, 1998b). Studying the foreststeppe vegetation mosaic on loess foothills, he developed a dynamic landscape morphological index based on successional distance and on the boundary length of patches (Fekete et al. 1998). This index described the successional situation and future prospect of the different vegetation patches in relation to neighbouring patches. This method was further developed, while studying the sand mosaics of the Great Hungarian Plain. His first choice was the sand oak forest-steppe forest, but he realised that their flora has become too poor for the gradient to be analysed at the forest-steppe mosaic scale. He was downcast finding a scientific question almost impossible to study. His next step was to examine the grassland mosaics on sand dunes, primarily focusing on the semi-open grassland type, characterised by the dominance of Festuca wagneri, where he analysed the mosaic of open, semi-open and closed sandy grasslands and the species pool of the patches. Using the newly developed distance distribution function index, he demonstrated that the relation of two vegetation types is frequently asymmetrical within a vegetation mosaic. The landscape ecological neighbourhood of sandy grasslands in the inner Pannonian forest-steppe zone differs from that of grasslands close to the forest zone, and this influences their species richness (Fekete and Fekete 1998, Fekete et al. 2002). Analysing the regional gradient of forest and steppe flora, he proved that the floristical gradient between the centre and the periphery is not symmetric. While forest species become rarer towards the drier, warmer central areas, the number of steppe species does not increase; in fact, it decreases as well. Besides, none of the species becomes rarer towards the forest zone. Thus the Pannonian forest-steppe zone is lopsided with its steppe-zone neighbour missing (Fekete et al. 2010).

By the 1990s the improving technological conditions (the development of remote sensing, informatics and statistical methods) offered the opportunity to conduct countrywide floristical and vegetation surveys. The political changeover generated a social demand for such research, and also provided the financial background. After 20 years (after a period with comparatively few field botanists) a new generation of young botanists and vegetation sci- 
entists appeared, and presented comprehensive syntheses. Gábor Fekete was excited and did everything in his power to help this process. Each and every researcher in the Hungarian ecology and botany mattered to him. He read everybody's works, knew everyone personally, including youngsters, often even prior to their first publications. He looked for the scientific substance in their publications. He pointed out the relevant references in the history of the discipline, and by his questions and suggestions he encouraged the young researchers to go further. His rightful critique always called attention to real deficiencies, and was based on a careful analysis, but above all, it showed that he really cared. His comments after conference presentations were also memorable. His questions helped and directed the speaker to talk about the important issues yet unmentioned, always referring to relevant points in the history of botany as well.

From the 1990s Gábor Fekete started to write strategic papers and books to help the renewal of floristics and vegetation science by promoting dialogue between the two disciplines (Fekete 1995, 1998a, 2004a, 2011, Fekete and Varga 2006, Fekete et al. 1997). His main purpose was to achieve quantitative syntheses that go far beyond the simple data collection and description. He did not like the overspecification, typical of many contemporary publications, in which there is no room to analyse a problem from diverse aspects, e.g. from a historical or multidisciplinary view. As if he was following Széchenyi's "the Greatest Hungarian's" footsteps: "I am seeking to combine good from the old and good from the new in the present" (Széchenyi 1831). He was looking for ways to synthesise old and new, and tried to call attention to new research questions, and to point out the gaps in our knowledge.

\section{DELINEATION OF THE PANNONIAN VEGETATION REGION}

In his last years he worked on the phytogeographical, in particular, on the vegetation-geographical synthesis of the Pannonian region. All through his life he admired Bálint Zólyomi's 'Map of natural vegetation' (first drafted in 1936, but repeatedly redrawn to incorporate new results up to the middle 1990s), which he thought to be the most important synthesis of the Pannonian vegetation. Gábor Fekete had a rich collection of literature on Pannonian vegetation, including articles in German, Czech, Slovakian, Ukrainian, Romanian, Serbian and Croatian. Based on these publications and his field experience, he combined and expanded Zólyomi's dynamic approach and Walter's zonality theory in his last two comprehensive works about the characteristics and boundaries of the Pannonian vegetation region (Fekete et al. 2014, 2016). In these papers, as often before, he developed new approaches. He classified the characteristics of vegetation into 3 main groups: regularities (e.g. the hori- 
zontal and vertical regional vegetation patterns), deviations ("unexpected", non-zonal patterns mostly resulting from mesoclimate, vegetation history or edaphic conditions), and unique features (e.g. endemic species, communities and vegetation mosaics) (Fekete et al. 2014). He also suggested a new approach in delineating biogeographical regions. He did not aim to draw any sharp borderline between two regions; instead, he wanted to know how far the region with vegetation dominated by typical Pannonian characteristics reaches. This led him to the conclusion that two neighbouring vegetation regions are not necessarily adjoining. Between the vegetation regions non-characteristic landscapes may occur, that is, areas without features characteristic of either of the neighbouring regions (e.g. the Sava-Drava area enclosed by the Pannonian, Alpine and Dinaric vegetation regions) (Fekete et al. 2016). He would be gratified if his model was used to describe and delineate the neighbouring biogeographical regions, and thus a new synthesis of Central European vegetation could be achieved.

\section{SCIENCE POLICY AND EDUCATION}

In addition to his work as a scientist and research manager, Gábor Fekete always considered teaching particularly important. He was involved in university education as an associate lecturer, supervisor of dissertations, editor and writer of textbooks as early as in 1967. He was teaching at several universities of Hungary at Budapest, Pécs, Debrecen, Szeged and Gödöllö, and regularly gave courses on vegetation science in the doctoral schools of three universities, thus helping and directing the training of the new generation of ecologists. In 1981 he was awarded the title of honorary professor of Loránd Eötvös University, Budapest. In the critical moments of Hungarian nature conservation, he was always on the frontline to stand up for the conservation of our natural heritage, and for the maintenance of the institutes in charge of it (e.g. Fekete 1999, 2003). He had a major role in making the Hungarian Academy of Sciences acknowledge that applied research (which is necessary for nature conservation practice) is just as important as basic scientific research, and that finding their optimal balance is of top priority (Fekete 2004b).

He got the candidate degree in 1966, and was awarded the title DSc in 1975. He was a member of the Committees on Biology, Ecology and Nature Conservation of the Hungarian Academy of Sciences, later also president of the latter two. He was elected to be a corresponding member of the Hungarian Academy of Sciences in 1987, and a regular member in 1995. Later he became a member of the Presidential Commission for Environmental Sciences, and of the Committee on Academic Publications. Beside his positions at the Academy, he worked several years in the UNESCO Hungarian National Commis- 
sion, and was also a member of the directory panel of the Hungarian Biological Society, and the vice president of its Ecological Department. He was the president of the EURECO congress in 1995 (Fekete 1997). He was working in the editorial board of several scientific journals (e.g. Acta Botanica Hungarica (editor-in-chief between 1980 and 1989), Phytocoenologia (from 1998), Kitaibelia (from 1999), and Tájökológiai Lapok (a journal on landscape ecology)).

He was keen to popularise the results of ecological studies; therefore, he was always ready to write, edit, or review monographs, encyclopaedias, or syntheses in multi-author teams (Fekete 2002, Fekete and Varga 2006). Committees of the Academy led by him regularly drafted declarations on the significance of ecological studies for the Hungarian society, and recommendations on potential ways forward.

In recognition of his contributions to Hungarian science, he was awarded the most prestigious Hungarian scientific prize, the Széchenyi award in 1999. He was given the Middle Cross Order of Merit of the Republic of Hungary in 2011.

You do not necessarily need a long time to create something long-lasting. Gábor Fekete would be remembered even if his life's work only consisted of his early floristical-phytosociological discoveries. The same could be said about the mature researcher, and each of his main studies on their own, whether they were about ecophysiology, demography, vegetation dynamics or community ecology. This applies even more to his comprehensive syntheses on the life-forms of plants, succession, degradation, climate change, the need for long-term ecological research, the relation of theory and empirism, the functioning of plant communities, the need for and the desirable content of modern vegetation monographs, the links between floristics and coenology, on quantitative biogeography, the new dynamic approach to the macrodifferentiation of vegetation, and on the essence and boundaries of the Pannonian vegetation.

But even without these publications, simply remembering the man himself, his person would set a lasting example of serenity and harmony, gallantry and humanity, mild critique and empathic care, modesty and wholeness. He was a person who admired the world around him, loved his colleagues, and was truly gratified by the creative activity of field work, research and teaching.

Acknowledgements - We thank László Orlóci, Beáta Oborny and Klára Virágh for their comments on earlier versions of the manuscript and to Brigitta Palotás for her assistance in English language editing. 


\section{SELECTED PUBLICATIONS}

This list is a selection of the most important publications of Gábor Fekete in chronological order. All are referred in the text.

Fekete, G. (1954): Chlorocyperus glaber (L.) Palla Magyarországon. (Chlorocyperus glaber (L.) Palla in Hungary). - Bot. Közlem. 45: 253-254.

Fekete, G. (1955): Die Vegetation des Velenceer Gebirges. - Annls hist.-nat. Mus. natn. Hung. 7: 343-362.

Fekete, G. and Jakucs, P. (1957): Néhány karsztbokorerdő-faj elterjedési adatainak katalógusa Magyarországról. (Distribution data of some species of karstic bush forests for Hungary). - Annls hist.-nat. Mus. natn. Hung. 8: 181-195.

Fekete, G. (1959a): Angaben zur Zönologie der moesischen Schwarzföhrenwälder. - Acta Bot. Hung. 5: 327-347.

Fekete, G. (1959b): Stipa bromoides (L.) Dörfl., eine neuentdeckte Pflanze in Ungarn. - Acta Bot. Hung. 5: 349-356.

Fekete, G. and Járai-Komlódi, M. (1962): Die Schuttabhangwälder der Gerecse- und Bakony-Gebirge. - Ann. Univ. Sci. Budapest, Sect. Biol. 5: 115-129.

Fekete, G. (1963): Verbreitungspunktkarte der Pflanzenarten des Bakony-Gebirges. I. Charakterarten der Schluchtwälder. - Fragmenta Botanica 3: 97-107.

Fekete, G. (1965): Die Waldvegetation im Gödöllőer Hügelland. Vergleichende pflanzengeographische Studie über die Wälder der kühl-kontinentalen Waldsteppe. Akadémiai Kiadó, Budapest, $223 \mathrm{pp}$.

Fekete, G. and Zólyomi, B. (1966): Über die Vegetationszonen und pflanzengeographische Charakteristik des Bakony-Gebirges. - Annls hist.-nat. Mus. natn. Hung. 58: 197-205.

Fekete, G. (1966): Der xerotherme Flaumeichen-Buschwald des nördlichen Bakony-Gebirges. Die Phytozönosen des Bakony-Gebirges. III. - Annls hist.-nat. Mus. natn. Hung. 58: 207-221.

Fekete, G. (1967): Der Wallnuss-Baumhasel-Felsenwald der Berge von Oltenien. - Annls hist.-nat. Mus. natn. Hung. 59: 163-173.

Fekete, G. and Jakucs, P. (1968): Der xerotherme Eichenwald des Bükk-Gebirges (CornoQuercetum). A Bükk hegység xerotherm tölgyerdője (Corno-Quercetum). - Bot. Közlem. 55: 59-68.

Fekete, G. (1972): A növénytársulás fiziognómiai struktúrája, a fény és a víz mint produkcióökológiai tényezők. (Physiognomic structure of plant communities, and light and water as production ecological factors). - MTA Biol. Oszt. Közlem. 15: 137-158.

Fekete, G. (1975): Interspecifikus kapcsolatok, kölcsönhatások és az ökológiai niche elemzése tölgyerdei fajokon. (Interspecific relations, interactions and the analysis of ecological niche of oak forest species). - DSc thesis, MTA, 14 pp.

Fekete, G., Précsényi, I., Molnár, E. and Melkó, E. (1976): Niche studies on some plant species of a grassland community. I. Comparison of various measurements. - Acta Bot. Hung. 22: 321-354.

Fekete, G. and Tuba, Z. (1977): Supraindividual versus individual homogeneity of photosynthetic pigments: a study on community structure. - Acta Bot. Hung. 23: 319-331.

Précsényi, I., Fekete, G., Melkó, E. and Molnár, E. (1977a): Niche studies on some plant species of a grassland community. II. Seasonal niche dynamics. - Acta Bot. Hung. 23: 193-218.

Précsényi, I., Fekete, G., Melkó, E. and Molnár, E. (1977b): Niche studies on some plant species of a grassland community. III. Overlap investigations by cluster analysis. - Acta Bot. Hung. 23: 369-374. 
Fekete, G., Précsényi, I., Horánszky, A. and Tölgyesi, Gy. (1979): Niche studies on some plant species of a grassland community. IV. Niche characteristic of Festuca vaginata populations on the basis of the macro- and microelement content of the soil and the plant. - Acta Bot. Hung. 25: 63-73.

Fekete, G. (1980): Die Vegetationskartierung in Ungarn. - Folia Geobot. Phytotax. 15: 193-196.

Fekete, G., Tuba, Z. and Précsényi, I. (1980): Niche studies on some plant species of a grassland community VII. Quantity and seasonality of photosynthetic pigments. - Acta Bot. Hung. 26: 289-297.

Fekete, G. and Précsényi, I. (1981): Niche structure of a perennial sandy grassland. - In: Stefanovits, P., Berczik, Á., Fekete, G. and Seidl, M. (eds): MAB Programme. Survey of 10 years activity in Hungary. Hung. Nat. MAB Committee, Budapest, pp. 67-102.

Fekete, G. and Virágh, K. (1982): Vegetációdinamikai kutatások és a gyepek degradációja. (Vegetation dynamical studies and the degradation of grasslands). - MTA Biol. Oszt. Közlem. 25: 415-420.

Virágh, K. and Fekete, G. (1984): Degradation stages in a xeroseries: composition, similarity, grouping, coordination. - Acta Bot. Hung. 30: 427-459.

Fekete, G. (ed.) (1985a): A cönológiai szukcesszió kérdései. (About coenological succession). Akadémiai Kiadó, Budapest, 216 pp.

Fekete, G. (1985b): A terresztris vegetáció szukcessziója: elméletek, modellek, valóság. (Succession of terrestrial vegetation: theories, models and reality). - In: Fekete, G. (ed.): A cönológiai szukcesszió kérdései. (About coenological succession). Akadémiai Kiadó, Budapest, pp. 31-36.

Tuba, Z. and Fekete, G. (1986): Ökofiziológia és ökológia. Alapvetések, valamint példák a faji-populációs és társulásszintű megközelítésekre. (Ecophysiology and ecology. Foundations, and examples for species-population and community level approaches). - Bot. Közlem. 73: 197-204.

Fekete, G., Tuba, Z. and Melkó, E. (1988): Background processes at the population level during succession in grassland on sand. - Vegetatio 77: 33-41. https:// doi.org/10.1007/bf00045747

Fekete, G., Tuba, Z. and Précsényi, I. (1990): Niche space partition in a sandy grassland: parallel approaches for describing populations. - Abstracts, V. INTECOL, Yokohama, p. 46.

Fekete, G. (1992): The holistic view of succession reconsidered. - Coenoses 7: 21-29.

Fekete, G. and Tóthmérész, B. (1993): Vegetation science in Hungary. - J. Veg. Sci. 4: 279291. https://doi.org/10.2307/3236116

Zólyomi, B. and Fekete, G. (1994): The Pannonian loess steppe: differentiation in space and time. - Abstracta Botanica 18: 29-41.

Nagy, Z., Tuba, Z., Szente, K., Uzvölgyi, J. and Fekete, G. (1994): Photosynthesis and water use efficiency during degradation of a semiarid loess steppe. - Photosynthetica $\mathbf{3 0}$ 307-311.

Kovács-Láng, E. and Fekete, G. (1994): Long-term ecological research in Hungary. - In: Nottrott, R. W., Franklin, J. F. and van der Castle, J. R. (eds): International networking in long-term ecological researches. Proceedings of an international summit, Estes Park, Colorado, USA, Sept. 23-24, pp. 59-60.

Kovácsné-Láng, E. and Fekete, G. (1995): Miért kellenek hosszú távú ökológiai kutatások? (Why do we need long-term ecological research?). - Magyar Tudomány 40: 377-392.

Fekete, G. (1995): Fitocönológia és vegetációtan: hazai aszpektusok. (Phytosociology and vegetation science: Hungarian aspects). - Bot. Közlem. 82: 107-127. 
Fekete, G., Tuba, Z. and Précsényi, I. (1995): Application of three approaches to evaluate abundance and rarity in a sand grassland community. - Coenoses 10: 29-38.

Szente, K., Nagy, Z., Tuba, Z. and Fekete, G. (1996): Photosynthesis of Festuca rupicola and Bothriochloa ischaemum under degradation and cutting pressure in a semiarid loess grassland. - Photosynthetica 32: 399-407.

Fekete, G., Molnár, Zs. and Horváth, F. (eds) (1997): A magyarországi élőhelyek leírása, határozója és a Nemzeti Élóhely-osztályozási Rendszer. (Description of and guide to Hungarian habitats). - Magyar Természettudományi Múzeum, Budapest, 374 pp.

Fekete, G. (1997): Welcome by the President of EURECO'95. - Abstracta Botanica 21: 217.

Fekete, G., Virágh, K., Aszalós, R. and Orlóci, L. (1998): Landscape and coenological differentiation in Brachypodium pinnatum grassland. - Coenoses 13: 39-53.

Fekete, G. and Fekete, Z. (1998): Distance distribution between patch systems: a new method to analyse community mosaics. - Abstracta Botanica 22: 1-7.

Fekete, G. (1998a): Javaslat újtípusú vegetációmonográfiák megalkotásához. (Proposal for the preparation of modern vegetation monographies). - Kitaibelia 3: 71-73.

Fekete, G. (1998b): Vegetációtérképezés: visszatekintés és hazai körkép. (Vegetation mapping: history and the present Hungarian situation). - Bot. Közlem. 85: 17-30.

Fekete, G. (ed.) (1998c): A közösségi ökológia frontvonalai. (Front lines of community ecology). - Scientia, Budapest, 233 pp.

Kovács-Láng, E., Fekete, G. and Molnár, Zs. (1998): Mintázat, folyamat, skála: hosszú távú ökológiai kutatások a Kiskunságban. (Pattern, process and scale: long-term ecological research in the Kiskunság). - In: Fekete, G. (ed.): A közösségi ökológia frontvonalai. (Front lines of community ecology). Scientia, Budapest, pp. 209-224.

Fekete, G. (1999): Botanika, erdészet, természetvédelem. (Botany, forestry and nature conservation). - Kitaibelia 4: 347-355.

Fekete, G., Virágh, K., Aszalós, R. and Précsényi, I. (2000): Static and dynamic approaches to landscape heterogeneity in the Hungarian forest-steppe zone. - J. Veg. Sci. 11: 375382. https://doi.org/10.2307/3236630

Fekete, G. (2002): Biológiai, ökológiai és természetvédelmi címszavak. (Biology, ecology and nature conservation). (ca 3,000 entries). - In: Láng, I. (ed.): Környezet- és természetvédelmi lexikon I-II. (Lexicon on environmental and nature protection I-II). Akadémiai Kiadó, Budapest, 664 pp. (I), 588 pp. (II).

Fekete, G., Molnár, Zs., Kun, A. and Botta-Dukát, Z. (2002): On the structure of the Pannonian forest steppe: grasslands on sand. - Acta Zool. Hung. 48(Suppl. 1): 137-150.

Fekete, G. (2003): A biodiverzitás és jelentôsége. (Biodiversity and its relevance). - In: Glatz, F., Láng, I., Bedő, Z. and Csete, L. (eds): Növény, állat, élőhely. (Plants, animals, habitats). MTA Társadalomkutató Központ, Kossuth Kiadó, Budapest, pp. 17-39.

Fekete, G. (2004a): Cönológia és növényföldrajz. (Coenology and phytogeography). - Acta Acad. Paed. Agriensis, Sect. Biol. 25: 13-23.

Fekete, G. (2004b): Ökológia: a teóriától a praxisig. (Ecology: from theory to practices). Magyar Tudomány 110: 2-11.

Fekete, G. and Molnár, E. (2005): Természetes életközösségek, növénypopulációk válasza a klímaváltozásra. (Responses of natural communities and plant populations to climate change). - Bot. Közlem. 92: 173-187.

Fekete, G. and Varga, Z. (eds) (2006): Magyarország tájainak növényzete és állatvilága. (Vegetation and wildlife of Hungarian landscapes). - MTA Társadalomkutató Központ, Budapest, 460 pp. 
Bartha, S., Molnár, Zs. and Fekete, G. (2008): Patch dynamics in sand grassland: connecting primary and secondary succession. - In: Kovács-Láng, E., Molnár, E., Kröel-Dulay, Gy. and Barabás, S. (eds): The Kiskun LTER: Long-term ecological research in the Kiskunság, Hungary. Institute of Ecology and Botany, HAS, Vácrátót, pp. 31-34.

Fekete, G., Somodi, I. and Molnár, Zs. (2010): Is chorological symmetry observable within the forest steppe biome in Hungary? A demonstrative analysis of floristic data. Community Ecology 11: 140-147. https://doi.org/10.1556/comec.11.2010.2.2

Fekete, G. (2010): In memoriam Zoltán Tuba (1951-2009). - Acta Bot. Hung. 52: 1-8. https:// doi.org/10.1556/abot.52.2010.1-2.1

Bartha, S., Fekete, G., Nagy, Z., Csintalan, Zs., Fóti, Sz., Czóbel, Sz., Balogh, J., Németh, Z., Penksza, K., Szerdahelyi, T., Nagy, J. and Virágh, K. (2010): Sokféleség és szabályozottság - a szünfiziológia szerepe a modern társulásökológiában. (Diversity and regulation role of synphysiology in modern community ecology). - In: Bartha, S. and Nagy, Z. (eds): Botanikai, növényélettani és ökológiai kutatások. Tuba Zoltán professzor emlékének. (Botanical, plant physiological and ecological studies. In Memoriam Prof. Zoltán Tuba). SzIE, MKK Növénytani és Ökofiziológiai Intézet, Gödöllő, pp. 27-39.

Bartha, S., Campetella, G., Kertész, M., Hahn, L., Kröel-Dulai, Gy., Rédei, T., Kun, A., Virágh, K., Fekete, G. and Kovács-Láng, E. (2011): Beta diversity and community differentiation in dry perennial sand grassland. - Ann. Bot. 1: 9-18.

Fekete, G. (2011): Florisztika ma és holnap. (Floristics today and tomorrow). - Kitaibelia 15: 13-23.

Fekete, G., Molnár, Zs., Magyari, E., Somodi, I. and Varga, Z. (2014): A new framework for understanding Pannonian vegetation patterns: regularities, deviations and uniqueness. - Community Ecology 15: 12-26. https://doi.org/10.1556/comec.15.2014.1.2

Fekete, G., Király, G. and Molnár, Zs. (2016): Delineation of the Pannonian vegetation region. - Community Ecology 17: 144-124. https://doi.org/10.1556/168.2016.17.1.14 